\title{
Resistance as Sacrifice: Towards an Ascetic Antiracism
}

\author{
Musa al-Gharbi ${ }^{1}$
}

\begin{abstract}
Often described as an outcome, inequality is better understood as a social process: a function of how institutions are structured and reproduced, and the ways people act and interact within them across time. Racialized inequality persists because it is enacted moment to moment, context to context -- and it can be ended should those who currently perpetuate it commit themselves to playing a different role instead. This essay makes three core contributions: first, it highlights a disturbing parity between the people who are most rhetorically committed to ending racialized inequality and those who are most responsible for its persistence. Next, it explores the origin of this paradox - how it is that ostensibly antiracist intentions are transmuted into 'benevolently racist' actions. Finally, it presents an alternative approach to mitigating racialized inequality, one which more effectively challenges the self-oriented and extractive logics undergirding systemic racism: rather than expropriating blame to others, or else adopting introspective and psychologized approaches to fundamentally social problems, those sincerely committed to antiracism can take concrete steps in the real world - actions which require no legislation or coercion of naysayers, just a willingness to personally make sacrifices for the sake of racial justice.
\end{abstract}

Suggested citation: al-Gharbi, Musa (2019). "Resistance as Sacrifice: Towards an Ascetic Antiracism. Sociological Forum. DOI: 10.1111/socf.12544

${ }^{1}$ Paul F. Lazarsfeld Fellow in Sociology, Columbia University

Website: musaalgharbi.com

Email: musaalgharbi@gmail.com 


\begin{abstract}
"Racism is both overt and covert. It takes two closely related forms...we call these individual racism and institutional racism... The second type is... far more subtle, less identifiable in terms of specific individuals committing the acts. But it is no less destructive of human life. The second type originates in the operation of established and respected forces in society, and thus receives far less public condemnation than the first type... It is institutional racism that keeps black people locked in dilapidated slum tenements, subject to the daily prey of exploitative slumlords, merchants, loan sharks and discriminatory real estate agents. The society either pretends it does not know of this latter situation, or is in fact incapable of doing anything meaningful about it." (Ture \& Hamilton 1992, p. 4).
\end{abstract}

This passage, from Kwame Ture \& Charles Hamilton's Black Power: The Politics of Liberation, marks the first use of the term "institutional racism." The reality the authors described in 1967 remains distressingly familiar today. ${ }^{2}$ While overt expressions of what they called 'individual racism' have markedly declined in the intervening period (Bonilla-Silva 2017), vast disparities remain between blacks and whites in terms of education (Shedd 2015), employment (Western \& Pettit 2005) and wealth (Sullivan et al. 2015); discrimination in hiring and promotion continues (Quillian et al. 2017), as do the predatory lending practices targeting blacks which Ture and Hamilton condemned (Semuels 2018).

Social scientists often discuss these disparities as outcomes. However, inequality is probably better understood as a process (Abbot 2016, pp. 233-252) -- one sustained largely as a result of how systems and institutions are structured and reproduced, and the ways in which people act and interact within them across time. Systemic racism is not a product (outcome) of people holding the 'wrong' beliefs or feelings. It is a function of behavioral patterns -- and (unjust) allocations of resources and opportunities -- that systematically advantage some, and disadvantage others, within particular contexts. It persists because it is enacted moment to moment, situation to situation. It could be ended if those who currently perpetuate it committed themselves to playing a different role instead - not merely through their words or feelings, but with action. ${ }^{3}$

This essay makes three core contributions: first, it highlights a disturbing parity between those who are most rhetorically committed to ending racialized inequality and those most responsible for its persistence. Next, it explores the origin of this paradox - how it is that ostensibly antiracist intentions are transmuted into 'benevolently racist' actions. Finally, it presents an alternative approach to dismantling racialized inequality, one which more effectively challenges the self-oriented and extractive logics that undergird systemic racism: ascetic antiracism. Rather than expropriating blame to others, or adopting introspective and psychologized approaches to problems that are fundamentally social in nature, those sincerely committed to antiracism can take concrete steps in the real world - actions which require no legislation or coercion of naysayers, just a willingness to personally make sacrifices for the sake of racial justice.

\title{
ANTIRACIST WHITES, BAD FAITH, INEQUALITY
}

It would perhaps be a happy coincidence if racialized inequality could be resolved primarily (or exclusively) by focusing on those who hold 'unenlightened' racial beliefs and attitudes, those who fail to vote the 'right' way, etc. - i.e. requiring little-to-no change from the 'good whites' and how they live their

\footnotetext{
2 Most Americans overestimate the amount of progress that has been made (Kraus et al. 2017) - although most also recognize that 'more changes are needed' to achieve racial equality (Parker et al. 2016).

3 There is a sense in which we are only looking at one half of the equation here. After all, people of color often knowingly and actively take actions that reproduce inequality too (Rafanell \& Gorringe 2010) - albeit typically because they do not see viable alternatives (Babcock 2014, Mullainathan \& Shafir 2014). However, should the primary beneficiaries of contemporary racialized inequality change how they exercise their agency, it would open more possibilities for its primary casualties to do the same. Hence the focus here on those who profit most from the prevailing order and its racial dynamics.
} 
lives. In reality, the main obstacle to a more just distribution of resources and opportunities today may be those who acknowledge racism, identify with the left, and aspire to be (or view themselves as) allies to those from historically marginalized and disenfranchised groups. Consider:

America's wealth is being concentrated in urban, coastal regions, particularly the West Coast (Seattle through San Diego), Chicago, and the Northeast Corridor running from Boston, through New York to Washington D.C. (Manduca 2019; Frank 2018; Time Labs 2015). These regions also serve as hubs for the most lucrative and essential industries in today's economy - finance, consulting, law, technology, medicine (Yang 2018). Perhaps unsurprisingly, college graduates from around the country are increasingly flocking to these cities as well (Dougherty et al. 2018; Florida 2016). Indeed, these regions hosts the 'heart' of academia, including all of the Ivy League schools, the 'public ivies,' the elite liberal arts colleges, and a plurality of R1 schools. ${ }^{4}$ Media institutions have been consolidated into the same hubs, and increasingly cater to these elite constituencies' interests or preferences at the expense of virtually everyone else (Shafer \& Doherty 2017).

Minorities and immigrants have been heavily concentrated into these metropolitan areas as well. America's cities are more diverse than ever, yet they remain heavily segregated along racial and ethnic lines (Williams \& Emamdjomeh 2018). The places where wealth is being concentrated also happen to be the most unequal places in the United States -- with an ever-growing share of denizens classifying as either extremely well-off or impoverished (Galka 2017; Sassen 2018, pp. 235-72).

Although these areas do tend to have significantly higher taxes (Kiernan 2019) - largely to fund more generous social safety nets, infrastructure projects, and government services (Cohn 2012) - state and local tax revenues tend to be extracted at significantly higher rates from people in the lower quintiles of the income distribution (Cohen 2015). That is, it is the poor and middle classes who disproportionately fund the more generous social safety nets in these states and municipalities. Put another way, wealth is being concentrated into the hands of elites in these regions at a far higher clip than it is being reallocated to the disadvantaged.

In short, when we look at who we would have to reallocate wealth and opportunity from - whose lifestyles or behaviors would have to be adjusted for the sake of benefiting the poor and minorities -- it would primarily be relatively well-off whites who live in or around major metropolitan areas. And not just the super-rich. Since Occupy Wall Street, most discussions about elites have focused on the top 1\% of U.S. wealth-holders - often maligned as ostentatious, greedy, materialistic and entitled (Sherman 2017). Yet, as Richard Reeves (2017a) put it:

\begin{abstract}
"The rhetoric of 'We are the 99 percent' has in fact been dangerously self-serving, allowing people with healthy six-figure incomes to convince themselves that they are somehow in the same economic boat as ordinary Americans, and that it is just the so-called super rich who are to blame for inequality."
\end{abstract}

In fact, Reeves (2017b) shows, it is the upper and upper-middle classes who are responsible for the declines in social mobility and increased concentration of wealth in the uppermost quintiles. In their efforts to preserve their socioeconomic position and help their children advance further up the ladder (or at least, avoid sliding 'down'), upper-middle class families have effectively "captured" key sources of social capital, and zealously defend their hold on them. Because this "new American aristocracy" is overwhelmingly white (Stewart 2018), this hoarding of wealth and opportunity has not only exacerbated inequality, it has reinforced its racialization as well.

\footnotetext{
4 These schools produce a radically disproportionate share of all tenured faculty (Warner \& Clauset 2015). They set the dominant frames and research agendas (Wellmon \& Piper 2017), and shape policies and procedures (Altbach 2010), for colleges and universities nationwide. Despite being non-representative of most faculty or students nationwide, they also widely shape public perceptions and narratives about universities (Casselman 2016, Friedersdorf 2016).
} 
It has been estimated that the black-white income gap would have closed by roughly 30 percent over the last 50 years were it not for these consolidations (Manduca 2018).

Critically, those most responsible for this racial stratification trend left politically. These are the whites who most fervently denounce Donald Trump and his supporters for their alleged racism and xenophobia (al-Gharbi 2018a); they are the whites most likely to produce and consume antiracist content in academia or the media. ${ }^{5}$ In fact, highly-educated white liberals have come to be more 'woke' in their racial attitudes than the average black or Hispanic (Kaufmann 2019a; Yglesias 2019) - even to the point of expressing more positive sentiments towards racial or ethnic 'others' over their fellow whites (Goldberg 2019); they are the only U.S. racial or ethnic subgroup to exhibit such tendencies. That is, the whites who seem most preoccupied with racialized inequality also happen to be among those most responsible for its persistence.

The states hosting the aforementioned nexus of social and financial capital -- and accompanying stark racial and economic inequality -- tend to be solidly "blue." Within those states, districts containing major metropolitan centers where elites tend to work and live trend even further left -- and have been growing even "bluer" in recent cycles as a result of the professional class' tightening alignment with the Democratic Party (Piketty 2018). ${ }^{6}$ These regions may now be more homogenously liberal than they have ever been (Enos 2017). ${ }^{7}$ Consequently, given the current concentrations of financial and cultural capital -and ongoing demographic trends -- it is well within the power of liberal, urban, higher-SES whites to significantly upend the racial distribution of wealth in the United States purely through how they allocate their own resources, manage the organizations and institutions they are embedded in, and leverage the city and state governments which Democrats firmly control. Indeed, a growing body of evidence from the "global south" suggests that direct (especially sustained) transfers of cash or assets may among the most effective and efficient means of eliminating poverty and mitigating inequality (Hanlon et al. 2010; Matthews 2018). However, up to now, these whites have seemed averse to reallocating wealth or opportunities from themselves to the disadvantaged.

For instance, studies consistently show that the Americans who are most likely to give, and who dedicate the largest share of their income to charity, are actually those from the lower quintiles and in rural, suburban and/or "red" districts - particularly those who identify as religious or conservative (e.g. Davis et al. 2017; Zinsmeister 2016; Piff et al. 2010) ${ }^{8}$ These are also the donors whose charity is most directly oriented towards addressing poverty and human suffering. ${ }^{9}$ In contrast, wealthier, more-educated, urban donors (who trend left) are more likely to dedicate resources to causes like environmental protection or animal rights, or to organizations like the ACLU or Amnesty International (Callahan 2018). The largest charitable contributions by these donors consistently go to universities, especially elite private schools - and museums or the arts (Stern 2013) - i.e. to institutions which (disproportionately white) elites are, themselves, among the most likely to utilize.

\footnotetext{
5 Whites are dramatically overrepresented, and blacks and Hispanics significantly underrepresented, within academia to include social research fields. Social scientists are disproportionately white and even more disproportionately leftleaning (al-Gharbi 2018b). Similar patterns hold for journalists (Willnat et al. 2017).

${ }^{6}$ Even suburban districts where wealth is concentrated have increasingly been trending "blue" (Geismer \& Lassiter 2018).

${ }^{7}$ Most poor people in America today live in "red" districts; the areas seeing increases in poverty tend to be suburban communities, particularly within "red" states (Kneebone 2016) -- which have long tended to receive more than they contribute in federal income taxes (Tierney 2014).

${ }^{8}$ Even higher-income individuals who live in rural, suburban, less economically-polarized areas (which trend "red") tend to be more generous than their socio-economic peers who live in highly-unequal areas (Cote et al. 2015).

${ }^{9}$ A recent study (Hall et al. 2018) found similar patterns in attitudes versus actions with respect to environmentalism: Those who believed in climate change were much more supportive of federal policies to protect the environment, but climate change skeptics tended to have more environmentally-friendly lifestyles and behaviors.
} 
Even when these elites invest in public spaces like parks, they often work to tightly restrict access thereafter - particularly with regards to minorities and the poor (Toloudi 2016; Jaffe 2014).

The higher one goes up the socioeconomic ladder, and the larger the individual donations get, the more donors try to leverage their 'gifts' into greater social influence (Horvath \& Powell 2017). 'Charity' is often used to directly promote elite donors' financial interests ${ }^{10}$ (Mukherjee \& Banet-Weiser 2012), or to distract attention from the role elites played in creating or perpetuating social problems (Kotkin 2018). In other cases, philanthropy is used to kill more systemic social reforms that may better address the issues elites want to 'fix,' but would threaten their financial interests in the process (Giridharadas 2018). Uppermiddle class and wealthy taxpayers also tend to be much more aggressive in using charitable donations to reduce their tax liability. This significantly reduces government revenues, ${ }^{11}$ thereby undermining state-led efforts to assist the disadvantaged too (Williamson 2019).

Nowhere are these dynamics clearer than with regards to antiracism. Again, given the abundance of coverage on inequality (and racial inequality in particular) among academic and media outlets primarily produced for, and consumed by, (disproportionately white) social elites - it would be reasonable to assume that those who control most financial and cultural capital in the United States also harbor deep and sincere egalitarian commitments. Yet, even as their actions and interactions both racialize and exacerbate inequality, less than $7 \%$ of all philanthropic dollars in the U.S. are awarded to groups that specifically serve ethnic or racial minorities (Brown et al. 2016, p. 9). Out of the 1,000 largest charitable foundations in the United States, the overwhelming majority (90\%) dedicate less than half of their grant dollars to directly assisting underserved communities; overall, underserved communities receive less than one-third of all charitable foundation funding (Schlegal 2016). ${ }^{12}$

As Jerolmack \& Khan (2014) noted, "talk is cheap": To understand what people really believe, one must look at behaviors. Should we rely on "where and how people invest their resources" as a measure of their priorities and commitments (Becker 1978) - regardless of whether one looks at rates of donation, the share of wealth donated, or the specific organizations/ institutions/ causes supported when these donors $d o$ give - it seems as though addressing inequality is simply not a priority for the uppermiddle class and wealthy urban (or urban-adjacent) whites who control the lion's share of financial, social and cultural capital in the United States (and trend politically 'left'). Addressing the racialization of inequality seems to be even less of a concern.

\footnotetext{
10 Mirroring the "doing well by doing good" mentality among upper-income or upwardly-mobile, highly-educated urban whites, companies have been increasingly highlighting their charitable giving, or even taking 'bold' stances on culture-war issues -- signaling towards antiracism, feminism or LGBTQ rights, etc. -- as a way of selling more of their products and services to this key financial demographic, who seem to (literally) buy into these symbolic gestures despite these companies' actual track records and ongoing behaviors with respect to their employees, contractors, the environment, etc. (Iqbal 2019; Holder 2017; Abad-Santos 2018).

11 Despite being less likely to give -- and tending to give less of their overall income away than lower SES Americans - the relatively well-off are much more likely to itemize charitable deductions. In virtue of their falling into higher tax brackets, government revenues are drained much more by write-offs from these taxpayers than those from the lower and middle classes. According to an analysis by the Tax Policy Center (2018, p. 262), each dollar in charitable donations from the bottom $60 \%$ of the income distribution reduced the federal government's income by less than 4 cents. However, the cost to the government of every charitable dollar increases rapidly in the upper quintiles. At the pinnacle of the distribution, each philanthropic dollar from someone in the top $1 \%$ of earners reduced government funds by 32 cents. The Tax Policy Center estimates that charitable donations cost the federal government around $\$ 44$ billion in tax revenues for 2018 alone, overwhelmingly via deductions from people making $\$ 100 \mathrm{k}$ per year or more. And of course, state governments also take a hit insofar as they allow charitable deductions on their taxes too (most do).

12 Perhaps the most striking aspect of these statistics is the broad and inclusive definition of 'underserved communities' utilized in the study: domestic workers, economically disadvantaged people, immigrants and refugees, incarcerated and formerly incarcerated people, LGBTQ people, people of color, people with disabilities, people with HIV/ AIDS, sex workers, women and girls or victims of crime and abuse (Schlegal 2016, Appendix A). All of these groups combined receive less than a third of all U.S. charitable foundation funding, and the vast majority of American charitable foundations dedicate less than half of their grants to helping any of these groups - individually or collectively.
} 
Nonetheless, it would be overly simplistic to dismiss white elites as merely cynical or deceptive in their antiracist commitments. They often seem genuinely horrified by racialized inequality and its consequences, despite the ways in which they benefit from these dynamics, and despite their own lack of meaningful action to change them. As Jean-Paul Sarte (1956) put it:

\begin{abstract}
"Let us understand clearly that there is no question of a reflective, voluntary decision, but of a spontaneous determination of our being. One puts oneself in bad faith as one goes to sleep, and one is in bad faith as one dreams. Once this mode of being has been realized, it is as difficult to get out of it as to wake oneself up; bad faith is a type of being in the world, like waking or dreaming, which by itself tends to perpetuate itself" (p. 113).
\end{abstract}

Next, we will explore one key mechanism through which this 'bad faith' is maintained: moral credentialing.

\title{
WHITE PRIVILEGE, MORAL CREDENTIALING, BENEVOLENT RACISM
}

It has become fashionable today, particularly within left-leaning and academic circles, to "call out" others for their privilege, to insist that people recognize and "check" their racial privilege, and to denounce anyone who refuses to do so as "racist" (Maltz-Bovy 2017). Conveniently lost is the reality that not all whites get the same "mileage" out of their whiteness. A thought experiment to drive this point home:

Imagine that you are six-inches taller than the national average. This would give you many unearned benefits relative to others who were average height or below-average height. For instance, one would have a competitive advantage in many sports (Samaras 2007) or in the dating market (Stulp et al. 2013); tall people also tend to live longer (Olds 2016) and earn more money (Pinsker 2015). However, if you lived in a community where virtually everyone else is also six-inches taller than the national average, you would not gain much from your height. You would not have a competitive advantage over others in your community in terms of sports, dating, employment, etc. It may be the case that if some people of below-average height moved into your community, you (and everyone else) would have a competitive advantage over them. Moreover, in a community where virtually everybody is taller than the national average, it is certainly better to be taller-than-average oneself than to not be taller than the national average. But none of this changes the reality that, in your day-to-day life, your "extra" height avails you little vis-à-vis others in your community. Relative to your circumstances, you are average. How would one get the most utility out of being six-inches taller than the national average? By living in a community where most others were average or (even better) shorter than average. So it goes with most other unearned advantages.

As with height, the premium one gets on their "whiteness" is relational and context-dependent. Racial privilege is also intersectional: just as racial disadvantage is compounded by poverty (Jargowsky 2015), white privilege is enhanced by relative wealth. Among the people with the most racial privilege, then, would be upper-SES or upwardly-mobile whites who live in areas with large concentrations of significantly less well-off minorities and immigrants. Again, these whites tend to be highly-educated, urban-dwelling and left-leaning. They also tend to leverage their racial privilege at a rate, and on a scale, that dwarfs lower-SES, less-educated, non-urban whites (who are more likely to identify as Republican or conservative and dismiss the racial privilege narrative).

Consider, for instance, "lean-in" feminism. As Saskia Sassen points out (2009, p.3), highlyeducated women of middle and upper-class backgrounds have achieved great gains in the professional sector (particularly in urban areas). However, this has not come about due to some major change in gender roles - for instance, because men have taken on a reciprocally larger share of domestic responsibilities. 
Instead, native-born, higher-SES white women have been "freed up" because other women - typically women of color, often immigrants, generally paid below-market wages for their services - fulfill the traditional "female" roles within the household, such as caring for children, preparing/ serving meals (be it at home or in restaurants), cleaning the house, attending to the sick and elderly, etc. (Stack 2019). ${ }^{13}$

Or, consider the popularity of delivery services among upper-middle and high-SES urban residents: groceries, meals from restaurants, merchandise purchased online or in-store - transported to one's apartment or workplace in short-order, cheaply, with the push of a button. Fulfilling these orders is grueling, high-pressure work; deliverers are exposed daily to road hazards, the elements and, occasionally, predation (i.e. being robbed). Wages tend to be very low and benefits non-existent (Rutigliano 2018). Within urban areas, the people filling these jobs are disproportionately immigrants and minorities (Haque 2018). ${ }^{14}$

Similar patterns hold with regards to delivering people: rideshare companies like Uber and Lyft are especially popular among the (disproportionately white) professional class because they provide cheap transportation virtually anytime, anywhere, on demand. However, while taxi jobs used to provide livable wages and benefits to low-skilled immigrants and minorities, rideshare companies are able to outcompete them on price because they subsidize rides to the point of operating at a loss (Horan 2019), outsource expenses like insurance, gas, vehicle acquisition and maintenance to the drivers themselves (Robinson 2018), and offer such low wages that contractors typically have to work well-over full-time just to make ends meet if this is their only "gig" (Gilligan 2016). Public transportation systems have also taken a hit from rideshare companies (Hill 2018), leading to cuts (viz. staffing, routes, maintenance) and/ or increased fares - disproportionately affecting lower-income and minority residents.

Or consider the "urban manufacturing" of high-quality, small-batch, specialized (or 'artisanal') goods sold in trendy, high-end or boutique stores -- increasingly popular among the disproportionately white and left-leaning metropolitan professional class (Currid-Halkett 2017). These "American made" wares are typically produced in urban sweatshops, often by undocumented workers receiving subpar wages, few benefits, and working under horrible conditions (Sassen 2018). Similar dynamics hold for restaurants offering "organic," "fair-trade," "free-range" or otherwise "ethically-sourced" products: given the cost of the ingredients themselves, establishments often try to keep their prices relatively affordable (for upper-middle class people) by paying subpar wages to "back of the house" workers who, disproportionately, tend to be immigrants and minorities (Jayaraman 2013).

One could go on and on: where wealth is being concentrated in America today, minorities (and especially immigrants) are disproportionately likely to do domestic work, food service, retail, construction, janitorial, groundskeeping, security and maintenance jobs - providing the infrastructure and services empowering people from the (disproportionately white) professional class to do their work, and live their lives in relative comfort and ease (Harvey 2012).

\footnotetext{
13 Similar dynamics hold with regards to sex. Contemporary American adults report having less sex with their partners than previous cohorts - a trend that is especially pronounced among highly-educated and married couples (Twenge et al. 2017). Yet there has been a corresponding increase in demand for prostitution, particularly in urban areas, facilitated by online platforms to connect sex workers to "johns" (Chan et al. 2019). "Hobbyists" - i.e. those who regularly connect to sex workers through internet sites like The Erotic Review -- are disproportionately white, married, highly-educated and financially well-off: More than $84 \%$ are above the median national income in the United States; a plurality (43\%) make $\$ 120$ k per year or more. $79 \%$ have a B.A. or higher, with a plurality (41\%) possessing graduate degrees. More than $84 \%$ are white (Monto \& Milrod 2014). Meanwhile, cis and trans women of color comprise the vast majority of sex workers nationwide (Dank et al. 2014).

14 At the initial phase of the merchandise delivery process are processing and fulfillment centers. These are precarious and low-wage jobs (Sammon 2019); working conditions often resemble sweatshops, with insufficient climate control or breaks, relentless tracking of production, and constant pressure to increase output (Godlewski 2018, Edwards 2013, Spicer 2018). These positions are disproportionately filled by blacks and Hispanics (Greene 2015).
} 
These "invisible" workers often live precarious lives (Heller \& Ortiz 2017) - facing down high costs of living, uncertain employment, long hours, low wages, few benefits, poor schools, pollution, fear of crime and law enforcement...

In short, despite being more willing than most other whites to acknowledge their privilege, midto-upper SES whites who live in (or adjacent to) major metropolitan areas tend to exploit people of color, immigrants and low-SES workers at levels that would be virtually inconceivable to denizens of Oklahoma or Idaho - where service providers and their clients are much more likely to be the same race (white), and differences between classes are much less dramatic or pronounced (Berube 2018). This raises an uncomfortable question: given that recognizing privilege does not seem to have much to do with actually rectifying racial injustice -- what is the purpose of this rhetoric? Why put on a spectacle of condemning privilege while enjoying greater racial privilege than most whites, and continuing to actively exploit said privilege? A disturbing possibility: performative antiracism provides a 'moral license' for behaviors that perpetuate or exacerbate racialized inequality.

Research in the behavioral sciences suggests that when whites explicitly denounce racism, or affirm their commitment to racial equality, they often grow more likely to act in ways that favor other whites - yet simultaneously grow more confident that their actions were not racially-motivated (Monin \& Miller 2001). A similar effect holds when they observe others from their 'in-group' making gestures towards antiracism: it convinces them not only that their peers are egalitarians (Krumm \& Corning 2008), but that their own actions and interactions are non-biased as well (Kouchaki 2011). Conversely, blaming or denouncing 'others' for a particular moral failing reduces one's own sense of guilt for that same moral failing (Rothschild \& Keefer 2017). Hence, in an environment where those who benefit immensely from racialized inequality go around denouncing racism to one another constantly -- painting themselves as staunch advocates for racial justice -- it would become almost impossible for these people to actually see the role that they or their peers play in perpetuating systemic racism. And in part for this reason, these same whites would promote racialized inequality all the more, while feeling incredibly self-righteous about their egalitarianism.

This is, for instance, how so many whites in the Southern Poverty Law Center consistently privileged other whites in hiring and promotion - and created or tolerated a hostile environment for minorities within the organization with racist 'jokes,' racialized sexual harassment, etc. (Moser 2019) yet still managed to view themselves as champions for marginalized and vulnerable communities (Robinson 2019). Moral credentialing explains how white former NAACP chapter president and Africana Studies instructor Rachel Dolezal felt entitled to deceive people about her race, complete with a grotesque, stereotype-laden origin story and attempted hate crime hoaxes (Zavadski 2015) - yet still seemed to sincerely consider herself an advocate for the black cause. Even now that her fraud has been exposed, she continues to insist her 'transracialism' was always ultimately about liberating blacks from the illusion of race, rather than marking the ultimate expression of her white privilege (Oluo 2017). While these cases may represent the most extreme manifestations of this phenomenon, they may not be as unrepresentative as one may hope. Recent ethnographic work on racial activist groups suggests committed white nationalists and white antiracists often share "a common understanding of what racial identity is, and more importantly, what it should be" (Hughey 2012, p. 13). 'Benevolent racism' is a helpful frame for understanding how these dynamics play out:

"Unlike other forms of post-civil rights racism, benevolent racism is not predicated on the usual process of deracialization... rather than invoking the liberal ideal of 'neutrality' or color-blindness as a way to dodge, deny, or defend the racialized social system that supports White privilege (as with other types of post-civil rights racisms), benevolent racism ostensibly acknowledges and often condemns a system of White privilege. 
However, it does so in a way that further legitimizes and reinforces racist attitudes, policies, and practices in the name of 'benevolent' aims - i.e., in the name of supporting, empowering, and/or defending the Black community" (Esposito \& Romano 2014, p. 69). ${ }^{15}$

Consider: in areas of concentrated poverty that are being gentrified, or that lie adjacent to wealthier areas (as is often the case in urban settings), policing tends to be much more frequent and aggressive - even for small crimes (Fayyad 2017). Yet these areas tend to be strongly "blue" (Edsall 2018). Indeed, those calling the cops on people of color for things like taking shelter from the rain (Meara 2018), failing to wave at a white passerby while leaving their AirBnB (Victor 2018), sitting in their car waiting for yoga class to start (Muhammad 2018), accidentally brushing up against a white person in a store (Mays \& Piccoli 2018), selling water on the street or barbequing in a public park (Murdock 2018), etc. - the people regularly seeking out law enforcement for things like loud music, loitering, 'suspected' criminal activity, or domestic disturbances (Levin 2015) - these tend to be relatively well-off, highlyeducated, liberal, white denizens who are eager to "clean up" or "protect" their adopted neighborhood (Ingraham 2015). This is benevolent racism in action. ${ }^{16}$ In practice, they are using police to punish people of color who are insufficiently deferent to their demands or preferences (Weaver 2018) - but their ostensibly antiracist convictions make it impossible for them to see this. After all, they often moved into these neighborhoods in the first place because they were 'historic' 'cultured' and 'diverse' (Hyra 2017).

Performative antiracism has also become a status symbol among urban, highly-educated elites -- a signal to institutional gatekeepers that one deserves to be among other 'enlightened' souls (Salam 2018). In the early $19^{\text {th }}$ century, there was a concept of noblesse oblige: aristocrats demonstrated that they were (morally) worthy of their privilege by performatively recognizing that they were privileged, and then pledging to use that privilege for the benefit of all - especially the less fortunate (Deneen 2018). Today, elites demonstrate their worthiness - that they belong among the Google, New York Times and Ivy League crowd - by rhetorically (purely rhetorically) disassociating from their privilege. That is, not only is performative antiracism a means through which elites conceal their own role in perpetuating racialized inequality (including from themselves), it is also a social currency used to demonstrate one's elite status at great cost:

\footnotetext{
15 Despite asserting that benevolent racism is "discernable among various politicians, judges, journalists, civic leaders, and scholars of all races and across political lines," Esposito \& Romano primarily relied on conservatives and Republicans for their examples. This is surprising because people on the left are more likely to ostensibly champion black empowerment or condemn white privilege. As a result, one would expect examples of benevolent racism to be more common and readily apparent on the left (with other expressions of racism more prevalent on the right). Consider, for instance, 'competence downshifting': white liberals often seem to patronize minorities in a misguided attempt to better affiliate with them. This is not something conservatives generally do (Dupree \& Fiske 2018).

${ }^{16}$ Social elites have consistently increased policing and incarceration of blacks in the service of ostensibly noble, liberal, technocratic goals. For instance, in the early 20th century, leaders of the progressive social reform movement sought to rationalize and humanize capitalism. Under these auspices they instituted immigration restrictions, redlining, and even eugenics programs to contain and diminish minority populations -- held to be too large 'for their own good' (Leonard 2017). During the Truman era, the carceral state was established ostensibly to protect African Americans from 'mob justice' and insufficiently-professionalized law enforcement (Murakawa 2014). During the civil rights era, LBJ declared a "War on Crime" in order to help 'respectable' black leaders take control and transform their communities. This led to much more aggressive policing and surveillance of black communities, much higher levels of incarceration among blacks, and much more severe sentences for those convicted of crimes (Hinton 2016). But notice, all of these moves were justified under the auspices of positive, liberal, goals - allegedly to help African Americans themselves! Nonetheless, each of these maneuvers ultimately served to institutionalize and reinforce racialized inequality - using law enforcement to suppress resistance every step of the way.
} 
In The New Jim Crow, Michelle Alexander (2012) highlights how elites turn poor and working class whites and people of color against one another - thereby preventing the emergence of any transracial, class-based, solidarity that could threaten their own financial interests or social position. Her analysis focused on tactics most prevalent on (albeit far from exclusive to) the right, such as scapegoating minorities for social problems or encouraging a distinctly white conception of American nationalism. However, performative antiracism is another way upper-middle class and wealthy whites (particularly those aligned with the left) turn whites and people of color from the lower quintiles against one another, intentionally or not: By appearing almost-exclusively concerned with minority groups and their alleged needs or preferences, by constantly denigrating whiteness and villainizing poor and working-class whites, elite 'antiracists' often end up reaffirming racist narratives - i.e. middle and working-class whites' values, interests, culture and way of life are under siege; minorities will rise up at their expense, etc. The increased prevalence of these perceptions has been intimately, and perhaps causally, related to the contemporary resurgence of white identity politics (Kaufmann 2019b; Jardina 2019).

Nor is it lost on whites from the lower quintiles that the people calling on them to acknowledge their privilege, etc. happen to be benefitting far more from 'the system' than they are, but do not seem to be making any significant sacrifices for the sake of racial justice themselves. Consequently, antiracism often appears to be little more than a cynical power grab (as opposed to an authentic attempt to assist the disadvantaged). The perception that race / racism is primarily being used as a political cudgel by social elites to silence ${ }^{17}$ 'people like them' turns poor, working-class and middle-class whites against civil rights, civil liberties, minorities and the left more broadly. It also drives support for reactionary political leaders like Trump (Conway et al. 2017; Grossman 2018). ${ }^{18}$

In short, performative antiracism among white elites is both ubiquitous and highly-damaging. But what would it mean for upper-middle class and wealthy, urban, left-leaning whites to actually disassociate from their privilege? How can committed white antiracists meaningfully undermine, rather than reinforce, systemic racism? It is to these questions we now turn.

\section{TOWARDS AN ASCETIC ANTIRACISM}

Race is a social construction (Omi \& Winant 2014); racism is a function of social behaviors and relations. Racist ideologies are not the cause of systems, institutions or actions that perpetuate or exacerbate racialized inequality - they are produced to justify and legitimize these states of affairs (Kendi 2017). In other words, the actual practice of racialized group-making and inter-group competition is more fundamental than the popular discourses and ideologies which frame them (Loveman 1999). Yet many contemporary antiracist efforts -- especially among highly-educated, relatively well-off, white liberals focus primarily on 'hearts and minds' (beliefs, intentions, attitudes, feelings), symbols and rhetoric. Antiracism has largely shifted from a sociological project (focused on institutions, behaviors, the distribution of resources, etc.) into a psychological one (McWhorter 2019). Even sociologists seem to be increasingly adopting psychologized frameworks for understanding and advancing antiracism (e.g. Bonilla-Silva 2019).

Two assumptions seem to undergird this approach: first, that the primary obstacle to racial justice is a lack of awareness about the challenges people of color face, or the comparative advantages whites are presented with, or one's own culpability in perpetuating racialized dynamics, etc.

\footnotetext{
17 For instance, according to a recent Cato Institute survey, most (61\% of) Americans believe "people often call others racist or sexist to avoid having to debate with them" (Ekins 2017).

${ }^{18}$ As former (Trump) White House Chief Strategist Steve Bannon put it: "The longer [Democrats] talk about identity politics, I got 'em. I want them to talk about racism every day" (Kuttner 2017); "Race-identity politics...Just give me more. Tear down more statues. Say the revolution is coming" (Peters et al. 2017).
} 
Second, it is assumed that if people commit to antiracism in principle (as a result of being made aware of the realities of racialized injustice), they will cease inequality-generating behaviors in practice. Therefore, winning 'hearts and minds' will translate into changes in actions and interactions, or to reallocations of resources and opportunities. These tactics have proven ineffective, even counterproductive (e.g. Cooley et al. 2019; Dobbin \& Kalev 2016; Forscher et al. 2019; Wilton et al. 2019), because the assumptions they are based upon are false. As we have seen, awareness of systemic racism does not cleanly translate into actual behaviors that reduce inequality -- neither does supporting racial egalitarianism through words, beliefs or feelings. Indeed, among the primary beneficiaries and perpetuators of systemic racism today are whites who are already convinced of their privilege -- who both understand and lament the disadvantages people of color face. It is precisely these convictions that blind them to their own role in reinforcing racialized inequality (Ahmed 2004), thereby pushing them to look externally to identify culpable parties (i.e. the problem must be the 'bad' people who say, feel, or believe the 'wrong' things about others from historically marginalized or disadvantaged groups).

The primary challenge, therefore, is not to convince people to support antiracism in their 'hearts and minds' - but rather to mobilize those who already (ostensibly) support racial justice to act on those convictions, and to live in accordance with their professed values. The most meaningful act of resistance to systemic racism would be for its primary beneficiaries to seek ways to give of themselves - thereby subverting the system's self-oriented and extractive logics (Baudrillard 2017) -- rather than attempting to blame, coerce, cajole or expropriate from others under the auspices of antiracism.

Logistically speaking, this "ascetic" approach to addressing racialized inequality is easy. Some tactics have already been suggested in this paper: avoid "moral grandstanding" (Tosi \& Warmke 2016) on race. Abstain from itemizing charitable donations in an attempt to lower one's tax liability. Refrain from summoning the authorities against people of color in response to petty crimes, disputes or suspicions. Adopt a "yes in my back yard" (YIMBY) posture with regards to community development (Semuels 2017). ${ }^{19}$ Whenever possible, rely on carpooling, public transportation (or taxis) to get around instead of rideshare apps. Avoid delivery services - and be extraordinarily generous in tipping servers, delivery workers, et al. when their services are relied upon. ${ }^{20}$ Treat all service workers with dignity equivalent to one's peers. If in a position of authority, make extra effort to recruit, mentor, promote or admit qualified people of color - and work to ensure that all subordinate employees receive compensation that is both genuinely livable and representative of the value they bring to the organization. These are low-hanging fruit. Other tactics are a far greater test of one's antiracist commitment because, despite being technically easy to implement, they would often require far more significant changes to practitioners' lifestyles and aspirations.

19 Relatively well-off, highly-educated white liberals are among the strongest proponents for affordable housing (Edsall 2015) or accepting refugees (Ferwerda et al. 2017) in principle - yet often adopt a "not in my backyard" (NIMBY) position with regards to their own communities. In fact, as cities trend left, denizens tend to choke off new housing development (Kahn 2011). This increases costs of living and drives out poorer residents (Sorens 2018) - contributing significantly to racial segregation and the consolidation of minorities into areas of 'concentrated disadvantage' (Reeves 2017c, Rigsby 2016).

20 These efforts are not a replacement for political activism, but should go hand-in-hand with campaigns to ensure all service workers receive a fair wage from their employers irrespective of customers' generosity. Indeed, the history of tipped labor in the United States is steeped in racism. It grew popular, in part, as an attempt to avoid having to pay emancipated slaves an actual wage for their work. People of color, especially women, continue to disproportionately fill these positions today (Jayaraman 2016). Because their livelihood is contingent on the whims of their patrons, these workers often endure racism, sexism and other degrading and demeaning behaviors from customers in order to make a living. A telling statistic: in states that have guaranteed livable wages for service employees, workplace sexual harassment incidents are half as common as states without them (Robins 2018). 
For instance, the standard compensation for domestic workers should be at least the "formal economy" wage to hire a white person to provide equivalent services ${ }^{21}$ - regardless of the documentation status of the person hired, and whether or not the arrangement is "on" or "off" the books. Given the gender dynamics around domestic labor, this is both a feminist and an antiracist cause. However, putting it into practice would often require significant cuts to other spending, purely for the sake of paying a more just wage for the same domestic labor people currently receive. Many would have to rely a lot less on nannies and cooking or cleaning services if they adopted this practice. Some may be forced to reconsider the feasibility and costs of the dual-earner model altogether - and reckon with difficult issues involving the division of domestic duties - put off up to now because someone else was eating the costs (again, typically underpaid minority and/or immigrant women).

Alternatively, consider schooling: New York City swings decisively "blue" yet has one of the most racially-segregated school systems in the entire country (Harris \& Fessenden 2017). There is a widespread perception among elites that education deficits are the primary driver of inequality - rather than the relationship working the other way around (Hanauer 2019); there is also widespread support, in principle, for public schools. Yet few relatively well-off whites in New York City send their own children to their zoned public school (Douglas 2017). Many send their kids to private schools that charge tuition of tens-of-thousands per year but nonetheless market themselves as social-justice oriented institutions (Robin 2015). Others send their children to elite public schools, often outside their residential zone. These parents tend to vigorously oppose attempts by the city to increase students of color at these schools - be it through reserving places for low-income and/or minority students (Hylton 2018), including considerations of race or income in admissions, or reducing importance of standardized tests in admission decisions (Ali \& Chin 2018). Granted, this opposition is not usually grounded in antipathy towards blacks or Hispanics, but out of a drive to see their own children succeed (albeit, even at others' expense). Yet this is, fundamentally, how systemic racism operates. ${ }^{22}$

The absence of these relatively well-off white students at their zoned schools matters a lot. It is not simply an issue of decreased government revenue due to fewer "butts in chairs." The time, energy and other resources upper middle class and wealthy parents could dedicate to things like the PTA could make an immense difference at their zoned public schools (as they do for the elite schools they currently send their children to). A greater share of upwardly-mobile white peers would expose students of color to transformative networks, opportunities, and other forms of social and cultural capital (Briggs 2002). Conversely, relatively well-off white students would gain totally different understandings of race and privilege were they to attend majority black or Hispanic schools alongside many students from lowerincome backgrounds (Hagerman 2018); they would also grow significantly more likely to have interracial relationships as adults (Merlino et al. 2018). In short, it would be an absolute game-changer - for public schools, the students they serve, and the communities in which they are embedded -- were these leftleaning relatively well-off white parents to simply send their children to their zoned public schools.

\footnotetext{
21 In addition to general caretaking, minority or immigrant nannies are often expected to immerse children in another language and culture (Hua 2005). If these services are requested (or demanded) they should also be compensated - at the formal economy rate for a native-born white to provide a comparable education.

22 Another example: an upwardly-mobile white professional views themselves as an ally to African Americans. (S)he is on a job interview. An offer is made. However, the candidate recognizes that there seem to be no black people on the team. Would (s)he be likely to say, "I'm sorry, I cannot accept this position. Please hire a person of color in my stead. Let me connect you to some qualified people I know"? Almost certainly not. Despite an awareness of systemic racism, they would likely believe that they earned this opportunity on merit. Perhaps, after they take the job they may complain to their new colleagues about the lack of diversity, and claim the next person hired should be an African American if possible. But of course, so long as everyone who is in such a position makes that same calculation - take the opportunity, and then lament the lack of diversity (among their overwhelmingly white peers) - change will remain elusive.
} 
Not only would this make a big impact, it is also easy to implement (logistically speaking). In fact, it is far simpler than jumping through all the hurdles to secure a place for one's child at an elite school, paying (tens-of) thousands of dollars in tuition, then arranging for transportation there and back each day. It is also far more straightforward than the methods elites currently gravitate towards for 'bringing up' poor and minority students, i.e. pushing separate, privatized, experimental and idiosyncratic forms of educational funding and/or delivery on poor and minority students. Rather than developing institutional models that literally require sustained high levels of inequality in order to remain sensible, viable, and perhaps most importantly, profitable (Rooks 2017), ${ }^{23}$ elites could ensure that children attending local public schools receive the same education as their own children by simply sending their own children to those schools. There is no political resistance to overcome, no coalition to build prior all these families have to do in order to help significantly undermine systemic racism is yield to the default (their zoned public school). But of course, despite being so easy, for many, this is also very hard. It requires a willingness to deny perceived ${ }^{24}$ opportunities and advantages for oneself and one's family in order to give others a leg up. Plenty of higher-SES (highly-educated, urban dwelling, left-trending) whites care about racism enough to share (or write) an op-ed, take part in a demonstration, or other symbolic gestures of the sort. Far fewer seem willing to put actual "skin in the game" (Taleb 2018). Yet this is precisely what the situation demands:

Racialized inequality is a macro phenomenon that is generated primarily at the micro level, through individuals' behaviors in particular contexts over time. It can be unmade through a similar process. But it is important to bear in mind that it is a process. There are no quick or easy fixes for problems of this depth and scale. Isolated, sporadic, or short-term efforts will not suffice; the key is to change patterns of action, interaction and resource allocation across time. This is another reason for an ascetic approach to antiracism: Asceticism is a way of life; it is about giving up non-essential things in order to draw closer to what is genuinely good, true, or important (Hadot 1995). Ascetic antiracism entails the same. However, it remains to be seen how important racial justice actually is to those who perpetuate and benefit the most from (yet are also among the most vocal denouncers of) racialized inequality. This is a determination that can only be made with reference to action, or a lack thereof.

Here it may be tempting to define systemic racism as a collective action problem, and assert that an individual's sacrifices would be futile unless most other relatively well-off whites were also on board (thereby indefinitely delaying the obligation to make substantive changes to one's behaviors or lifestyle). In reality, the kinds of practical measures described here can have important and immediate effects within one's local community - especially for individuals who are struggling. The systemic effects would grow stronger given higher levels of participation, ${ }^{25}$ but this only reinforces the importance of whites who are

\footnotetext{
23 While the funding levels and pedagogical approaches more privileged children enjoy are reliably and demonstrably successful at preparing these students to flourish, the educational outcomes at voucher schools targeting poor and minority children tend to be worse, on average, than at the public schools these children would have otherwise attended (Carey 2017).

${ }^{24}$ Note the use of "perceived" here. In fact, studies show that for relatively well-off parents, there is little effect in terms of children's lifetime earnings from attending an elite school vs. not (Abdulkadiroglu et al. 2011) - or even having them attend an elite university vs. a less-selective one (Dale \& Krueger 1999; 2011). Those who tend to benefit most from attending elite schools are minority students, especially those from disadvantaged backgrounds. The effects are negligible for white children who are already relatively well-off. That is, practically speaking, these families would not be sacrificing much by simply sending their kid to their zoned public school. Instead, they'd be saving themselves a lot of effort and money - and doing real social good in the process.

25 As mentioned at the outset, this essay is focused on the primary beneficiaries of systemic racism (upper-middle class and wealthy whites who live in areas with large concentrations of immigrants and minorities), because these are the people who could most dramatically upend systemic racism through ascetic antiracism. However, it is important to note that relatively well-off people of color can also help dismantle racialized inequality by adopting this approach. In fact, this is essential -- lest elites from historically marginalized or disadvantaged groups be co-opted by the prevailing order, reproducing systemic prejudice through their own actions and interactions, merely directed towards others instead (Reed 2018).
} 
willing to lead on this issue. Often, all it takes is one person to serve as an exemplar for others to followsuit (Han et al. 2017); a single household can help inspire neighbors, friends, colleagues, and extended family. Young people can motivate their peers or inspire successive generations (Vaisey \& Lizardo 2016). Indeed, broader socio-normative changes often $d o$ arise in just this way, through the gradual diffusion of ideas and practices from local contexts outwards (Kincaid 2004, Bicchieri \& Mercier 2014). That is, the best solution for a collective action problem is for someone to step up and do the right thing (Willer 2009).

\section{CONCLUSION: FROM ZERO SUM TO EXCESS}

When confronted with the prospect of making personal sacrifices in order to achieve racial justice, a common response from relatively well-off (highly-educated, liberal, urban) whites is that antiracism does not have to be, and indeed should not be, a zero-sum game. This is true in a sense, albeit not the sense in which it is typically meant.

Again, the essential task for antiracists must be to challenge the self-oriented and extractive logics undergirding systemic racism. The 'do well while doing good' or 'rising tide lifts all boats' approaches are therefore doomed to fail because, as Audre Lorde put it (2007), "the master's tools will never dismantle the master's house." Indeed, we can see the failure of the 'grow the pie' model in the reality that the pie has been consistently growing over the past decades, yet inequality has been steadily growing as well because the wealthy -- aided and abetted by the upper middle-class -- have been taking an everlarger share for themselves (Piketty 2017).

In many respects, the prevailing order is founded on an understanding of human beings as homo economicus. Under this model, people are primarily self-regarding; we do (and should) work first and foremost to advance our own interests; the highest purpose of life is to be better than others. For the many who hold this view, ascetic antiracism would likely appear to run contrary to human nature - it may seem irrational for whites to willingly 'lose out' for the benefit of others.

Fortunately, homo economicus is not an accurate description of who we are as human beings, nor how we actually behave in the world (e.g. Bowles \& Gintis 2013). In many important respects, ${ }^{26}$ human relations are not defined by scarcity but by excess (Bataille 1985): What we all hunger for most of all is to be part of something bigger than ourselves - to find a purpose and/or a community to dedicate ourselves to. Precisely what brings meaning to our lives are the causes and people we invest ourselves in. This is the sense in which ascetic antiracism is not zero sum: it denies the premise upon which the notion is based. Giving of oneself does not impoverish, it enriches.

\footnotetext{
${ }^{26}$ For a great elaboration on this point - and an exploration of how understanding many social challenges as 'problems of excess' can change the way researchers approach the study of these phenomena (or seek to address them) - see Abbott 2016, pp. 122-159.
} 


\section{ACKNOWLEDGEMENTS}

Academic works are rarely composed alone, even when only a single author is listed. Many contributed to this project, not all of whom can be acknowledged here. But I would be remiss if I did not thank the Political Theory Project at Brown University for workshopping this paper with me at a PPE Research Seminar in its early stages. In particular, Dan D’Amico, Glenn Loury and John Tomasi provided important feedback. My colleagues at Columbia University were also extremely helpful in refining this work, especially Tiffany Huang, Greer Mellon, Estela Diaz, Francisco Lara, Diane Vaughn and Andreas Wimmer. I also owe a debt to Carla Shedd, now at City University of New York. I would like to offer special thanks to Shamus Khan, both for feedback provided at various stages of this project, and also for his groundbreaking work turning the sociological lens towards elites -- which served as a springboard for this essay. I am grateful to the anonymous reviewers at Sociological Forum, whose constructive criticism greatly improved this essay. Finally, I would like to celebrate editor Karen Cerulo for putting together this volume, for assembling a very helpful mini-conference at the Eastern Sociological Society meeting on these papers, and for her feedback and flexibility throughout this process.

\section{REFERENCES}

Abad-Santos, Alex. 2018. "Nike’s Colin Kapernick Ad Sparked a Boycott - and Earned \$6 Billion for Nike." Vox, September 24.

Abbot, Andrew. 2016. Processual Sociology. Chicago, IL: University of Chicago Press.

Abdulkadiroglu, Atila et al. 2011. "The Elite Illusion: Achievement Effects at Boston and New York Exam Schools." National Bureau of Economic Research, Working Paper No. 17264.

Ali, Syed \& Margaret Chin. 2018. "What's Going on With New York's Elite Public High Schools?” The Atlantic, June 14. Altbach, Philip. 2010. “Competition’s Impact on Higher Education.” Forbes, August 12.

Alexander, Michelle. 2012. The New Jim Crow: Mass Incarceration in the Age of Colorblindness. New York, NY: The New Press.

Ahmed, Sara. 2004. “Declarations of Whiteness: The Non-Performativity of Antiracism.” Borderlands 3:2.

Babcock, Elisabeth. 2014. "Using Brain Science to Design New Pathways Out of Poverty.” Crittenton Women's Union.

Bataille, Georges. 1985. Visions of Excess: Selected Writings, 1927-1939. Minneapolis, MN: University of Minnesota Press.

Baudrillard, Jean. 2017. Symbolic Exchange and Death. Los Angeles, CA: SAGE Publications Ltd.

Becker, Gary. 1978. The Economic Approach to Human Behavior. Chicago, IL: University of Chicago Press.

Berube, Alan. 2018. “City and Metropolitan Income Inequality Data Reveal Ups and Downs Through 2016.” Brookings, February 5.

Bicchieri, Cristina \& Hugo Mercier. 2014. "Norms and Beliefs: How Change Occurs.” In Maria Xenitidou \& Bruce Edmonds (eds.), The Complexity of Social Norms: pp. 37-54. Cham, CH: Springer.

Bonilla-Silva, Eduardo. 2019. "Feeling Race: Theorizing the Racial Economy of Emotions." American Sociological Review 84: 1: 1-25.

--- 2017. Racism Without Racists: Color-Blind Racism and the Persistence of Racial Inequality in America. Lanham, MD: Rowman \& Littlefield Publishers.

Bowles, Samuel \& Herbert Gintis. 2013. A Cooperative Species: Human Reciprocity and Its Evolution. Princeton, NJ: Princeton University Press. 
Briggs, Xavier de Souza. 2002. "Social Capital and Segregation: Race, Connections, and Inequality in America.” Kennedy School of Government, RWP02-011.

Brown, Kelly et al. 2016. "State of the Work: Stories from the Movement to Advance Diversity, Equity and Inclusion." D5 Coalition.

Callahan, David. 2018. The Givers: Power, Money and Philanthropy in a New Gilded Age. New York, NY: Vintage Press.

Carey, Kevin. 2017. “Dismal Voucher Results Surprise Researchers as DeVos Era Begins.” New York Times, February 23.

Casselman, Ben. "Shut Up About Harvard." FiveThirtyEight, March 30.

Chan, Jason et al. 2019. “The Digital Sin City: An Empirical Study of Craigslist's Impact on Prostitution Trends." Information Systems Research 30: 1: 219-238.

Cohen, Patricia. 2015. “Study Finds Local Taxes Hit Lower Wage Earners Harder.” New York Times, 13 January.

Cohn, Jonathan. 2012. “Blue States are from Scandinavia, Red States are from Guatemala.” New Republic, October 5.

Conway, Lucian III et al. 2017. "Donald Trump as a Cultural Revolt Against Perceived Communication Restriction: Priming Political Correctness Norms Causes More Trump Support.” Journal of Social and Political Psychology 5: 1: 244259.

Cooley, Erin et al. 2019. “Complex Intersections of Race and Class: Among Social Liberals, Learning About White Privilege Reduces Sympathy, Increases Blame, and Decreases External Attributions for White People Struggling with Poverty." Journal of Experimental Psychology: General. DOI: 10.1037/xge0000605

Cote, Stephanie et al. 2015. "High Economic Inequality Leads Higher Income Individuals to be Less Generous." Proceedings of the National Academy of Sciences 112: 52: 15838-15843.

Currid-Halkett, Elizabeth. 2017. The Sum of Small Things: A Theory of the Aspirational Class. Princeton, NJ: Princeton University Press.

Dale, Stacy \& Alan Krueger. 2011. "Estimating the Return to College Selectivity over the Career Using Administrative Earnings Data." National Bureau of Economic Research, Working Paper No. 17159.

--- 1999. "Estimating Payoff to Attending a More Selective College: An Application of Selection on Observables and Unobservables." National Bureau of Economic Research, Working Paper No. 7322.

Dank, Meredith et al. 2014. "Estimating the Size and Structure of the Underground Commercial Sex Economy in Eight Major U.S. Cities." Urban Institute, March.

Davis, Tyler, et al. 2017. “How America Gives, Data: Leaders, Laggards, Giving Opportunities and More." Chronicle of Philanthropy, October 2.

Deneen, Patrick. 2018. “The Ignoble Lie.” First Things 282: 27-32.

Dobbin, Frank \& Alevandra Kalev. 2016. “Why Diversity Programs Fail.” Harvard Business Review 94: 7: 52-60.

Dougherty, Danny et al. 2018. "Where Graduates Move After College.” Wall Street Journal, May 15.

Douglas, Dianna. 2017. “Are Private Schools Immoral?” The Atlantic, December 14.

Dupree, Cydney \& Susan Fiske. 2018. "Self-Presentation in Interracial Settings: The Competence Downshift by White Liberals." Journal of Personality and Social Psychology (in press).

Edsall, Thomas. 2018. “The Democrats' Gentrification Problem.” New York Times, April 19.

--- 2015. "Who Will Pay the Political Price for Affordable Housing?” New York Times, July 15.

Edwards, Jim. 2013. "Brutal Conditions in Amazon's Warehouses Threaten to Ruin the Company's Image." Business Insider, August 5.

Ekins, Emily. 2017. “The State of Free Speech and Tolerance in America.” Cato Institute, October 31.

Enos, Ryan. 2017. The Space Between Us: Social Geography and Politics. Cambridge, UK: Cambridge University Press. 
Esposito, Luigi \& Victor Romano. 2014. "Benevolent Racism: Upholding Racial Inequality in the Name of Black Empowerment." The Western Journal of Black Studies 38: 2: 69-83.

Fayyad, Abdallah. 2017. “The Criminalization of Gentrifying Neighborhoods.” The Atlantic, December 20.

Ferwerda, Jeremy et al. 2017. "Explaining Opposition to Refugee Resettlement: The Role of NIMBYism and Perceived Threats." Science Advances 3: 9: e1700812

Florida, Richard. 2016. “The U.S. Cities Winning the Battle Against Brain Drain.” CityLab, March 15.

Forscher, Patrick et al. 2019. “A Meta-Analysis of Procedures to Change Implicit Measures.” Journal of Personality \& Social Psychology. DOI: 10.31234/osf.io/dv8tu

Frank, Robert. 2018. "States with the Most Millionaires Per Capita.” CNBC, February 7.

Friedersdorf, Conor. 2016. “The Typical College Student Is Not Who You Think It Is.” The Atlantic, July 1.

Galka, Max. 2017. “America’s Geography of Wealth: The Shrinking Urban Middle Class Visualized.” The Guardian, May 17.

Geismer, Lily \& Matthew Lassiter. 2018. “Turning Affluent Suburbs Blue Isn’t Worth the Cost.” New York Times, June 9.

al-Gharbi, Musa. 2018a. "Race and the Race for the White House: On Social Research in the Age of Trump." The American Sociologist 49: 4: 496-519.

--- 2018b. "Data on How Ideological (Under) Representation Compares to (Under) Representation Along the Lines of Race, Gender or Sexuality.” Heterodox Academy, March 29.

Gilligan, Andrew. 2016. “Fears Over 'Excessive and Unsafe' 65-Hour Weeks for Uber Cab Drivers." The Telegraph, April 30.

Giridharadas, Anand. 2018. Winner Take All: The Elite Charade of Changing the World. New York, NY: Knopf.

Godlewski, Nina. 2018. “Amazon Working Conditions: Urinating in Trash Cans, Shamed to Work Injured, List of Employee Complaints." Newsweek, September 12.

Goldberg, Zach. 2019. “America’s White Saviors.” Tablet, June 5.

Greene, Jay. 2015. “Amazon Far More Diverse at Warehouses than in Professional Ranks.” Seattle Times, August 14.

Grossman, Matthew. 2018. "Racial Attitudes and Political Correctness in the 2016 Presidential Election." Niskanen Center, May 10.

Hadot, Pierre. 1995. Philosophy as a Way of Life: Spiritual Exercises from Socrates to Foucault. Oxford, UK: WileyBlackwell.

Hagerman, Margaret. 2018. White Kids: Growing Up With Privilege in a Racially-Divided America. New York, NY: New York University Press.

Hall, Michael, et al. 2018. "Believing in Climate Change, But Not Behaving Sustainably: Evidence from a One-Year Longitudinal Study." Journal of Environmental Psychology 56: 55-62.

Haque, Zubaida. 2018. "How the Gig Economy is Widening Racial Inequality.” New Statesman, February 8.

Han et al. 2017. "Attainable and Relevant Moral Exemplars Are More Effective than Extraordinary Exemplars in Promoting Voluntary Service Engagement.” Frontiers in Psychology 8: 283.

Hanauer, Nick. 2019. “Better Schools Won’t Fix America.” The Atlantic, July issue.

Hanlon, Joseph et al. 2010. Just Give Money to the Poor: The Development Revolution from the Global South. Sterling, VA: Kumarian Press.

Harris, Elizabeth \& Ford Fessenden. 2017. "The Broken Promises of Choice in New York City Schools.” New York Times, May 5. 
Harvey, David. 2012. “The Urban Roots of Financial Crises: Reclaiming the City for Anti-Capitalist Struggle.” Socialist Register 48: 1-35.

Heller, Jake \& Erik Ortiz. 2017. “Temp Work Now a Permanent Fixture, Creating Problems for 'Invisible' Workforce." NBC News, August 31.

Hill, Steven. 2018. "Ridesharing Versus Public Transit.” American Prospect, March 27.

Hinton, Elizabeth. 2016. From the War on Poverty to the War on Crime: The Making of Mass Incarceration in America. Cambridge, MA: Harvard University Press.

Holder, Alex. 2017. “Sex Doesn’t Sell Anymore, Activism Does. And Don’t Big Brands Know It.” The Guardian, February 3.

Horan, Hubert. 2019. “Uber's Path of Destruction." American Affairs 3: 2: 108-133.

Horvath, Aaron \& Walter Powell. 2017. "Contributory or Disruptive: Do New Forms of Philanthropy Erode Democracy?" Stanford Social Innovation Review, January 9.

Hua, Vanessa. 2005. "Bilingual Baby! Many Parents Want Nannies Fluent in Another Language to Help Tutor Their Kids." SF Gate, November 28.

Hughey, Matthew. 2012. White Bound: Nationalists, Antiracists, and the Shared Meanings of Race. Palo Alto, CA: Stanford University Press.

Hylton, Antonia. 2018. "Rich Parents in New York Are Mad their Schools Are Trying to Desegregate." Vice News, June 12.

Hyra, Derek. 2017. Race, Class and Politics in the Cappuccino City. Chicago, IL: University of Chicago Press.

Ingraham, Christopher. 2015. "These Cops Are Tired of White People Getting Freaked Out by their Black Neighbors." Washington Post, May 6.

Iqbal, Nosheen. 2019. "Woke Washing? How Brands Like Gillette Turn Profits by Creating a Conscience." The Guardian, January 19.

Jaffe, Eric. 2014. “The Hidden Ways Urban Design Segregates the Poor.” Fast Company, August 12.

Jardina, Ashley. 2019. White Identity Politics. Cambridge, UK: Cambridge University Press.

Jargowsky, Paul. 2015. “Architecture of Segregation.” The Century Foundation, August 7.

Jayaraman, Saru. 2016. Forked: A New Standard for American Dining. Oxford, UK: Oxford University Press.

--- 2013. Behind the Kitchen Door. Ithaca, NY: Cornell University Press.

Jerolmack, Colin \& Shamus Khan. 2014. "Talk is Cheap: Ethnography and the Attitudinal Fallacy." Sociological Methods \& Research 43: 2: 178-209.

Kaufmann, Eric. 2019a. “Americans Are Divided by Their Views on Race, Not Race Itself.” New York Times, March 18. --- 2019b. Whiteshift: Populism, Immigration, and the Future of White Majorities. New York, NY: Abrams Press.

Kahn, Matthew. 2011. “Do Liberal Cities Limit New Housing Development? Evidence from California.” Journal of Urban Economics 69: 2: 223-228.

Kendi, Ibram. 2017. Stamped from the Beginning: The Definitive History of Racist Ideas. New York, NY: Nation Books.

Kiernan, John. 2019. “2019 Tax Rates By State.” WalletHub, March 12.

Kincaid, Lawrence. 2004. "From Innovation to Social Norm: Bounded Normative Influence." Journal of Health Communication 9: Sup. 1: $37-57$

Kneebone, Elizabeth. 2016. "Poverty Crosses Party Lines.” Brookings, November 3.

Kotkin, Joel. 2018. "Watch Out! Here Come the 'Woke’ Tech Oligarchs." The Daily Beast, July 7. 
Kouchaki, Maryam. 2011. "Vicarious Moral Licensing: The Influence of Others' Past Moral Actions on Moral Behavior." Journal of Personality and Social Psychology 101: 4: 702-715.

Kraus, Michael et al. 2017. "Americans Misperceive Racial Economic Equality." Proceedings of the National Academy of Sciences 114: 39: 10324-10331.

Krumm, Angela \& Alexandra Corning. 2008. "Who Believes Us When We Try to Conceal Our Prejudices? The Effectiveness of Moral Credentials with In-Groups Versus Out-Groups.” Journal of Social Psychology 148: 6: 689-710.

Kuttner, Robert. 2017. “Steve Bannon, Unrepentant.” The American Prospect, August 16.

Leonard, Thomas. 2017. Illiberal Reformers: Race, Eugenics, and American Economics in the Progressive Era. Princeton, NJ: Princeton University Press.

Levin, Sam. 2015. “Racial Profiling Via Nextdoor.com.” East Bay Express, October 7.

Lorde, Audre. 2007. “The Master's Tools Will Never Dismantle the Master's House.” In Sister Outsider: Essays and Speeches: pp. 110-114. Berkeley, CA: Crossing Press.

Loveman, Mara. 1999. “Is ‘Race’ Essential?” American Sociological Review 64: 6: 891-898.

Maltz-Bovy, Phoebe. 2017. The Perils of 'Privilege': Why Injustice Can't Be Solved by Accusing Others of Advantage. New York, NY: St. Martin's Press.

Manduca, Robert. 2019. “The Contribution of National Income Inequality to Regional Economic Divergence." Social Forces. DOI: $10.1093 / \mathrm{sf} / \mathrm{soz} 013$

--- 2018. “Income Inequalities and the Persistence of Racial Economic Disparities." Sociological Science 5: 182-205.

Matthews, Dylan. 2018. "Giving Out Cash is a Great Way to Fight Poverty. This Approach Might be Even Better." Vox, October 15.

Mays, Jeffery \& Sean Piccoli. 2018. “A White Woman, Teresa Klein, Called the Police on a Black Child She Falsely Said Groped Her." New York Times, October 12.

McWhorter, John. 2018. “The Virtue Signalers Won’t Change the World.” The Atlantic, December 23.

Meara, Paul. 2018. "Video of White Lady Calling Cops on Black Woman for Standing in Doorway to Take Shelter from Storm." BET, August 2.

Merlino, Luca et al. 2018. "More Than Just Friends? School Peers and Adult Interracial Relationships." Journal of Labor Economics. DOI: 10.1086/702626

Monin, Benoit \& Dale Miller. 2001. "Moral Credentials and the Expression of Prejudice." Journal of Personality and Social Psychology 81: 1: 33-43.

Monto, Martin \& Christine Milrod. "Ordinary or Peculiar Men? Comparing Customers of Prostitutes With a Nationally Representative Sample of Men." International Journal of Offender Therapy and Comparative Criminology 58: 7: 802820.

Moser, Bob. 2019. “The Reckoning of Morris Dees and the Southern Poverty Law Center." New Yorker, March 21.

Muhammad, Latifah. 2018. “White California Woman Calls Cops on Black Man Sitting In His Car Waiting for Yoga Class to Start." Vibe, July 13.

Mukherjee, Roopali \& Sarah Banet-Weiser. 2012. "Commodity Activism in Neoliberal Times." In Roopali Mukherjee \& Sarah Banet-Weiser (eds.), Commodity Activism: Cultural Resistance in Neoliberal Times: pp. 1-22. New York, NY: New York University Press.

Mullainathan, Sendhil \& Eldar Shafir. 2014. Scarcity: The New Science of Having Less and How It Defines Our Lives. New York, NY: Picador.

Murakawa, Naomi. 2014. The First Civil Right: How Liberals Built Prison America. Oxford, UK: Oxford University Press. 
Murdock, Sebastian. 2018. "White Woman Threatened to Call Cops on 8-Year-Old Girl Selling Water." Huffington Post, June 23.

Olds, Tim. 2016. "The Long and Short of It: Eight Reasons Why Short Men Come Up Short." The Conversation, March 21.

Oluo, Ijeoma. 2017. "The Heart of Whiteness: Ijeoma Oluo Interviews Rachel Dolezal, the White Woman Who Identifies as Black." The Stranger, April 19.

Omi, Michael \& Howard Winant. 2014. Racial Formation in the United States. New York, NY: Routledge.

Parker, Kim et al. 2016. "On Views of Race and Inequality, Blacks and Whites Are Worlds Apart." Pew Research Center, June 27.

Peters, Jeremy et al. 2017. "Trump's Embrace of Racially-Charged Past Puts Republicans in Crisis." New York Times, August 16.

Piff, Paul et al. 2010. "Having Less, Giving More: The Influence of Social Class on Prosocial Behavior." Journal of Personality and Social Psychology 99: 5: 771-784.

Piketty, Thomas. 2018. “Brahmin Left vs Merchant Right: Rising Inequality and the Changing Structure of Political Conflict." World Inequality Database, Working Paper Series 2018: 7.

--- 2017. Capital in the Twenty-First Century. New York, NY: Belknap Press.

Pinkser, Joe. 2016. “The Financial Perks of Being Tall.” The Atlantic, May 18.

Quillian, Lincoln et al. 2017. "Meta-analysis of Field Experiments Shows No Change in Racial Discrimination Over Time." Proceedings of the National Academy of Sciences 114: 41: 10870-10875.

Rafanell, Irene \& Hugo Gorringe. 2010. “Consenting to Domination? Theorising Power, Agency and Embodiment with Reference to Caste." The Sociological Review 58: 4: 602-622.

Reed, Adolph Jr. 2018. “Antiracism: A Neoliberal Alternative to a Left.” Dialectical Anthropology 42: 2: 105-115.

Reeves, Richard. 2017a. “Stop Pretending You're Not Rich.” New York Times, June 10.

--- 2017b. Dream Hoarders: How the American Upper-Middle Class is Leaving Everyone Else in the Dust, Why That is a Problem, and What to Do About It. Washington D.C.: Brookings Institution Press.

--- 2017c. “"Exclusionary Zoning’ is Opportunity Hoarding by Upper Middle Class.” Brookings Institute, May 24.

Rigsby, Elliot. 2016. "Understanding Exclusionary Zoning and Its Impact on Concentrated Poverty." The Century Foundation, June 23.

Robin, Corey. 2015. “Elites Hold ‘Conversations’ About Race, While Resegregating Our Schools.” Salon, March 8.

Robins, Spencer. 2018. “Are Eaters the Key to Better Restaurant Wages and Working Conditions?” Civil Eats, August 14.

Robinson, Nathan. 2019. "The Southern Poverty Law Center is Everything that's Wrong with Liberalism." Current Affairs, March 26.

--- 2018. “Maybe Taxi Drivers Don’t Hate Progress, Maybe They Just Don’t Want to be Poor.” Current Affairs, March 2.

Rooks, Noliwe. 2017. Cutting School: Privatization, Segregation, and the End of Public Education. New York, NY: The New Press.

Rothschild, Zachary \& Lucas Keefer. 2017. “A Cleansing Fire: Moral Outrage Alleviates Guilt and Buffers Threats to One's Moral Identity.” Motivation and Emotion 41: 2: 209-229.

Rutigliano, Olivia. 2018. "The Serve-Us Industry." The Baffler, August 16.

Salam, Reihan. 2018. “The Utility of White-Bashing.” The Atlantic, August 6.

Samaras, Thomas. 2007. “Advantages of Taller Human Height.” In Thomas Samaras (ed.), Human Body Size and the Laws of Scaling: pp. 33-45. Hauppauge, NY: Nova Science Publishers. 
Sammon, Alexander. 2019. “Elwood, Illinois (Pop. 2,200), Has Become a Vital Hub of America’s Consumer Economy. And It's Hell." New Republic, January 9.

Sarte, Jean-Paul. 1956. Being and Nothingness. New York, NY: Washington Square Press.

Sassen, Saskia. 2018. Cities in a World Economy. New York, NY: SAGE Publications.

--- 2009. "The Other Workers in the Advanced Corporate Economy." Scholar \& Feminist Online 8: 1.

Schlegal, Ryan. 2016. "Pennies for Progress: A Decade of Boom for Philanthropy, A Bust for Social Justice." Washington D.C.: National Committee for Responsive Philanthropy.

Scott, James. 1999. Seeing Like a State: How Certain Schemes to Improve the Human Condition Have Failed. New Haven, CT: Yale University Press.

Semuels, Alana. 2018. “A House You Can Buy, But Never Own.” The Atlantic, April 10.

--- 2017. "From 'Not in My Backyard' to 'Yes in My Backyard.'” The Atlantic, July 5.

Shafer, Jack \& Tucker Doherty. 2017. “The Media Bubble is Worse Than You Think.” Politico, May/June issue.

Shedd, Carla. 2015. Unequal City: Race Schools and Perceptions of Injustice. New York, NY: Russel Sage Foundation.

Sherman, Rachel. 2017. Uneasy Street: The Anxieties of Affluence. Princeton, NJ: Princeton University Press.

Sorens, Jason. 2018. “The Effects of Housing Supply Restrictions on Partisan Geography.” Political Geography 66: 4466.

Spicer, Andre. 2018. “Amazon’s ‘Worker Cage’ Has Been Dropped, But Its Staff Are Not Free.” The Guardian, September 14.

Stack, Megan. 2019. Women's Work: A Reckoning with Work and Home. New York, NY: Doubleday.

Stern, Ken. 2013. "Why the Rich Don't Give to Charity." The Atlantic, April.

Stewart, Matthew. 2018. "The 9.9\% Is the New American Aristocracy.” The Atlantic, June.

Stulp, Gert et al. 2013. "Women Want Taller Men More Than Men Want Shorter Women.” Personality and Individual Differences 54: 8: 877-883.

Sullivan, Laura et al. 2015. “The Racial Wealth Gap: Why Policy Matters.” Demos, June 21.

Taleb, Nassim. 2018. Skin in the Game: Hidden Asymmetries in Daily Life. New York, NY: Random House.

Tax Policy Center. 2018. Briefing Book: A Citizen's Guide to the Fascinating (Though Often Complex) Elements of the Federal Tax System. Washington D.C.: Tax Policy Center.

Tierney, John. 2014. "Which States Are Givers and Which Are Takers?" The Atlantic, May 5.

Time Labs. 2015. “America’s Wealth Map.” Time, October 5.

Toloudi, Zenovia. 2016. “Are We in the Midst of a Public Space Crisis?” The Conversation, June 7.

Tosi, Justin \& Brandon Warmke. 2016. “Moral Grandstanding.” Philosophy \& Public Affairs 44: 3: 197-217.

Ture, Kwame \& Charles Hamilton. 1992. Black Power: The Politics of Liberation. New York, NY: Vintage Books.

Twenge, Jean et al. 2017. "Declines in Sexual Frequency Among American Adults, 1989-2014." Archives of Sexual Behavior 46: 8: 2389-2401.

Vaisey, Stephen \& Omar Lizardo. 2016. “Cultural Fragmentation or Acquired Dispositions? A New Approach to Accounting for Patterns of Cultural Change." Socius 2: 1-15.

Victor, Daniel. 2018a. “A Woman Said She Saw Burglars. They Were Airbnb Guests.” New York Times, May 8. Warner, Joel \& Aaron Clauset. 2015. “The Academy’s Dirty Secret.” Slate, February 23. 
Weaver, Vesla. 2018. "Why White People Keep Calling the Cops on Black Americans.” Vox, May 29.

Wellmon, Chad \& Andrew Piper. 2017. "Publication, Power and Patronage: On Inequality and Academic Publishing." Critical Inquiry, July 21.

Western, Bruce \& Becky Pettit. 2005. “Black-White Wage Inequality, Employment Rates, and Incarceration.” American Journal of Sociology 111: 2: 553-578.

Willer, Robb. 2009. "Groups Reward Individual Sacrifice: The Status Solution to the Collective Action Problem." American Sociological Review 74: 1: 23-43.

Williams, Aaron \& Armand Emamdjomeh. 2018. “America Is More Diverse Than Ever -- But Still Segregated." Washington Post, May 10.

Williamson, Vanessa. 2019. “The Philanthropy Con.” Dissent, Winter.

Willnat, Lars et al. 2017. The American Journalist in the Digital Age: A Half-Century Perspective. New York, NY: Peter Lang Publishing, Inc.

Wilton, Leigh et al. 2019. "Valuing Differences and Reinforcing Them: Multiculturalism Increases Race Essentialism." Social Psychological and Personality Science 10: 5: 681-689.

Yang, Andrew. 2018. The War on Normal People: The Truth About America's Disappearing Jobs and Why Universal Basic Income Is Our Future. New York, NY: Hachette Books.

Yglesias, Matthew. 2019. “The Great Awokening." Vox, April 1.

Zavadski, Katie. 2015. “How Did White Rachel Dolezal Convince Everyone She Was Black?” The Daily Beast, June 12.

Zinsmeister, Karl. 2016. “Who Gives Most to Charity?” In Almanac of American Philanthropy: pp. 1169-1182.

Washington D.C.: Philanthropy Roundtable. 